\title{
Glucocorticoids in Leprosy Reversal reaction
}

\author{
Renni YUNIATI, Matthew BRIAN KHRISNA \\ Department of Dermatology and Venereology, Diponegoro University, Semarang, Indonesia \\ *Correspondence: Renni Yuniati, E-mail: renniyuniati@yahoo.com \\ UDC 616.5-002.73-08:615.357.06
}

\begin{abstract}
Leprosy is a disease that is caused by Mycobacterium leprae which results in lots of disabilities in the patients. Leprosy is treated by multi-drug therapy regimen; however, this therapy might cause leprosy reactions in the patients. There are several types of lepromatous reaction: type 1 reaction, type 2 reaction and neuritis. Type 1 reaction mainly occurs in BB, BL and BT forms of leprosy and is characterized by exacerbation of preexisting lesions. The therapy of this reaction according to the WHO guideline is corticosteroid therapy. This article will explain several key points related to the corticosteroid therapy in leprosy reversal reactions, including the side effects and alternative therapies available.
\end{abstract}

Key words: Leprosy; Gene Expression Profiling; Glucocorticoids; Comorbidity; Diagnosis; Prednisolone; Indonesia

\section{Introduction}

Leprosy is a disease that has already existed for a long time and remains a significant health burden in a lot of nations worldwide up to this day. Leprosy, which is caused by $M y$ cobacterium leprae, can affect peripheral nerve systems and cause disability. The initial symptoms of leprosy are hypopigmented patches with hypoesthesia or anesthesia. However, these symptoms are often ignored by the patients, hence patients often present with more severe symptoms of leprosy, mainly nerve damage symptoms (numbness and weakness of the limbs). According to the WHO, the diagnosis of leprosy can be made if one of the following cardinal signs are met: (i) the presence of hypopigmented macules or erythematous macules with loss of sensorium sensation in the affected area, (ii) thickening or enlargement of peripheral nerves, (iii) discovery of acid-resistant bacteria on the slit-skin smear preparation (1).
Immunological reactions in leprosy are often found during treatment or after the completion of multi-drug therapy (MDT). There are two major types of lepromatous reactions: Type 1 (reversal) reaction, and Type 2 (ENL) reaction (2). Type 1 reaction mainly occurs in non-polar forms of leprosy (BB, BT, and BL forms); however, it could sometimes happen in a subset of LL patients that received MDT regimen (3). Forms of leprosy reactions that could possibly happen in each type of leprosy are described in Table 1. Type 1 reactions, also known as reversal reactions, are delayed-type (type IV) immunological reactions which have become the major cause of persistent disability. Type I reactions are more prevalent than Type II reactions in the patients receiving multi-drug therapy regimen (4).

Most of the cases of reversal reaction are diagnosed at the same time with leprosy itself or during the first two years of receiving MDT therapy; however, the highest incidence of

Table 1. Leprosy reactions that could possibly happen in each of the leprosy clinical forms (Adopted from Nery J, et al) ${ }^{3}$

\begin{tabular}{lcccc} 
Pausibacillary Patients & \multicolumn{4}{c}{ Multibacillary Patients } \\
\hline TT & BT & BB & BL & LL \\
\hline \multirow{2}{*}{$(-)$} & & & Type 2 (ENL) & Type 2 (ENL) \\
& Type 1 (RR) & Type 1 (RR) & Type 1 (RR) & \\
\hline
\end{tabular}


reversal reactions themselves happens during the $6^{\text {th }}$ month up to the $12^{\text {th }}$ month after MDT therapy is started, and then gradually declines $(2,5)$. Patients having "borderline tuberculoid" form of leprosy have shorter interval from the introduction of therapy to the development of reversal reactions, usually as short as 3-9 months. "Borderline lepromatous" patients have longer intervals (15 months), and the interval is even longer in "lepromatoid lepromatous" patients (up to two years). Reversal reactions usually recur less than ENL reactions (3). Recurrences of reversal reactions happen in about $31.8 \%$ of patients (6).

Some of the conditions that might increase the risk of reversal reactions are vaccination, chemotherapy, and puerperium. These conditions might increase the risk of reversal reactions due to the underlying changes such as improvement in cell immunity after pregnancy, intercurrent infections, stress, trauma, and oral contraceptive administration (3). Another study in Nepal found that seropositivity to anti-phenolic glycolipid-I, positive bacterial index, and a disease in more than two body areas were also identified as risk factors for type 1 reaction (7). The development of cutaneous type 1 reaction has a significant correlation with facial patches, and the development of neural type 1 reaction has a significant correlation with enlarged ulnar nerves. The presence of IgM antiPGL-1 antibodies is one of the independent risk factors in the development of type 1 reactions. PGL-1 itself is a product of viable Mycobacterium leprae (7). Coinfections with viruses and bacteria might also increase the risk of type 1 reactions in lepromatous patients; and leprosy patients could also have immunological characteristics that would impair the clearance of certain type of viruses, most notably hepatitis $B$ virus (HBV) and hepatitis C virus (HCV) (8).

Type 1 reactions result from the activation of cellular immunity against antigens of Mycobacterium leprae (3). Clinically, the expression of this reaction is exacerbation of skin and nerve trunk inflammation, which results in motor and sensory alterations. This reaction is different from Type 2 reactions, where there

Table 2. Differences in type 1 and type 2 reactions in leprosy

\begin{tabular}{|c|c|c|}
\hline & Reversal reaction (Type 1) & ENL (Type 2) \\
\hline Leprosy category & $\begin{array}{l}\text { Borderline (borderline tuberculoid, } \\
\text { borderline borderline, borderline lepromatous) }\end{array}$ & $\begin{array}{l}\text { Lepromatous leprosy, } \\
\text { borderline lepromatous }\end{array}$ \\
\hline Skin lesion & $\begin{array}{l}\text { Transformation of the existing lesion into an } \\
\text { edematous and reddish lesion } \\
\text { Distribution: similar to the existing lesion site }\end{array}$ & $\begin{array}{l}\text { Newly formed erythematous dermal or } \\
\text { subcutaneous modules } \\
\text { Painful } \\
\text { Distribution: upper and lower extremities, } \\
\text { face, back, abdomen }\end{array}$ \\
\hline $\begin{array}{l}\text { Signs and } \\
\text { symptoms }\end{array}$ & $\begin{array}{l}\text { Edema on upper and lower extremities } \\
\text { Neuritis: painful sensation on nerves, } \\
\text { newly occurring anesthesia } \\
\text { Sudden loss of motoric function: claw hand, } \\
\text { foot drop, facial palsy }\end{array}$ & $\begin{array}{c}\text { Fever, anorexia, malaise } \\
\text { Arthralgia, myalgia } \\
\text { Neuritis } \\
\text { Epididymitis, orchitis } \\
\text { Lymphadenitis } \\
\text { Hepatosplenomegaly } \\
\text { Glomerulonephritis } \\
\text { Iridocyclitis } \\
\text { Lobular panniculitis } \\
\text { Dermal and subdermal edema }\end{array}$ \\
\hline $\begin{array}{l}\text { Histopathological } \\
\text { findings }\end{array}$ & $\begin{array}{l}\text { Edema in existing granulomas } \\
\text { Lymphocyte increase } \\
\text { Central fibrinoid necrosis in some of the } \\
\text { tuberculoid granulomas } \\
\text { Fusion of tuberculoid granulomas in the dermis }\end{array}$ & \\
\hline
\end{tabular}


are acute inflammatory reactions with systemic involvement which activates a plethora of pro-inflammatory cytokines such as IL-1, IL-6, IL-8 and TNF (3). The distinctive features of Type 2 reactions are the formation of new lesions instead of the transformation of the preexisting lesions, with more significant inflammation-related symptoms in the patient, as shown in Table 2. There is also another kind of lepromatous reactions called reactional neuritis, which affects the peripheral nerves. This reaction is characterized by sudden pain of palpation of peripheral nerve, whether spontaneous or promoted by compression of a nerve trunk, which can be accompanied with the thickening of nerve trunks (9). Neuritis may occur in patients without other signs of reaction. Type 1 reaction is diagnosed when there are hypopigmented macular skin lesions which have become reddish and edematous, with or without edema in the hands and feet. Damage to the sensory nerves can be characterized by spontaneous nerve pain and paresthesia. In worst cases, the patient can experience loss of pain sensation, therefore increasing his/her susceptibility to injury. Motor nerve damage generally occurs in the ulnar nerve, median nerve, communical nerve, facial nerve, and posterior tibialis peroneus which results in foot drop, wrist drop and facial palsy. Facial nerve involvement may cause lagophthalmos and keratitis, which might result in blindness $(10,11)$.

\section{Diagnosis of Reversal Reactions}

Reversal reactions are characterized clinically by increased inflammation of preexisting lesions, which are confirmed by clinical diagnosis (3). The hypopigmented macules that have already regressed since the introduction of treatment would turn red and edematous. In some rare cases, the lesion might become ulcerated. This might be accompanied with the presence of new lesions with similar characteristic to the reversal reaction lesions described above. In "borderline lepromatoid" patients, face or extremities edema might present, appearing by itself or together with another lesions. Sometimes, edema in the hands and/or feet could possibly be a key symptom of reversal reactions (3).

There are several clinical variants of the reversal reaction. In melanodermic patients, nodules/pseudonodules might be present, mostly on the face but could possibly arise in other areas, that resemble (and may be misdiagnosed as) erythema nodosum. Some of the lesions might appear similar to erysipelas, and the ulceration that happened might result in scars after resolution. Macular reverse reactions with hypochromic or erythematous maculae are common in patients with the borderline form after completing the specific treatment. This hypochromic or erythematous nodule is sometimes accompanied with local hypersensitivity. MB patients could experience cutaneous lesions that are similar to papulae and small disseminated plaques (9).

Reversal reactions might also involve nerves. Nerves could become thick and painful, eventually causing worsening of a previous peripheral neuropathy (in terms of motoric, sensory or autonomic functions). Upon physical examination, we can find nerve enlargement and pain when palpating the nerve. This might cause patients to complain that they felt burning sensation in skin lesion, pain in the extremities or on the face, accompanied with decreased muscular sensitivity and muscular strength. Monofilament test can be used as a screening test for sensory function abnormalities. This is done by doing bristle test using standard nylon monofilaments (12). Voluntary motor testing, using a numerical system, can be applied for examining the motor function. This test, when done regularly and carefully, could possibly assist in the early detection of a reaction. Deterioration of VMT may precede more obvious clinical signs (12). More sophisticated methods such as EMG, sensory and motor nerve conduction velocity testing, evoked response testing, and autonomic reflexes measurement do not significantly add diagnostic value to detect reversal reaction (12). A biopsy is not routinely done for reversal reactions; however, some of the hallmarks of reversal reactions are the formation of granulomas and dermal edema. Other signs that can be found are macrophage epithelial differentiation, increase in lymphocyte numbers, epidermal thickening, and destruction of nerves by granuloma infiltrates (2).

In a previous study, there was an increase of IFN-a, IL-10, and IL-17 levels and a decrease of IL-10 found in serological tests of patients diagnosed with reversal reactions. 
The ratio of proinflammatory cytokines with IL-10 can be used as an early diagnostic marker for reversal reactions and to evaluate the treatment (13). Another research concerning immune responses and gene expressions in the patients diagnosed with lepromatous reversal reaction found an elevation of IFN- $\gamma$, IP-10, CXCL9, IL-17A, and VEGF in the patients after the diagnosis of reversal reactions compared to the levels before they were diagnosed with reversal reaction. The elevation of these cytokine levels was also accompanied by diminished levels of $\mathrm{CD} 39^{+} \mathrm{CCL} 4^{+}$and CD25 high (14). Another study conducted by Andersson, et al. has found that blood TNF-a profiles do not have any diagnostic values for reversal reactions because they do not have a significant difference compared to healthy controls. The increase in TNF-a and its decrease after receiving prednisolone therapy are only found on the skin (15).

\section{Therapy of Reversal Reactions}

The therapy for reversal reactions aims to suppress the cellular immune response. Polychemotherapy should be continued throughout the episode of lepromatous reaction; whether it is reversal reaction or ENL. Corticosteroids are one of the most efficient drugs used in the therapy of reversal reactions, and are still mainly used in the therapy of reversal reactions. Corticosteroids reduce vascular permeability and vasodilation by inhibiting the mediators such as prostaglandins from arachidonic acids, and inhibiting the release of platelet-activating factors (PAF), vasoactive amines, neuropeptides, IL-1, TNF and nitric oxide. Glucocorticoids can inhibit the activation of neutrophil and eosinophil, reducing the adherence of neutrophil and eosinophil through the endothelial cells, and preventing the polymorphonuclear cells to migrate to the area with tissue inflammation. Glucocorticoids also inhibit the phagocytic capacity and production of oxygen free radicals, reducing the number of eosinophils circulating in peripheral bloods (causing rough granulation in polymorphonuclear neutrophils); they also inhibit the migration of monocytes and lymphocytes to the tissue with an increase in the endothelial adhesion of lymphocytes, as well as the vascular per- meability; including cellular migration and activation (3).

Corticosteroids have several effects on the disease course of reversal reactions. Corticosteroids reduce intraneural and cutaneous edema, therefore it results in the quick improvement of symptoms and reduces post inflammatory scarring (16). The main effect of corticosteroids is suppressing the inflammatory immune response to the antigens of $M y$ cobacterium leprae in the skin and nerves, by interfering with the activation of immune cellular response (3).

According to the $\mathrm{WHO}$, the standard therapy for type 1 leprosy reaction is prednisolone at a dose of $1 \mathrm{mg} / \mathrm{kgBW} /$ day for 12 weeks for paucibacillary cases, and for 24 weeks for multibacillary cases (17). The same therapeutic dose is also applicable in pediatric patients (18). Initial dose of $40 \mathrm{mg}$ prednisolone is sufficient to control most type 1 reactions (19). Patients with neural involvement need higher doses of prednisolone, sometimes up to $2 \mathrm{mg} / \mathrm{kgBW} /$ day (16). Prednisone dose should only be reduced following clinical improvement and upon reaching the dose of $20 \mathrm{mg} /$ day. General improvement of the symptoms begins to happen within three to six months (3). Prednisone should be continually given until clinical regression and neural functions are fully recovered (3). Sevalsekar et al. found complete remission after oral corticosteroid use (20). However, several studies have indicated that some of the nerve function impairment would eventually resolve without steroid therapy. This improvement might be spontaneous or might be attributable to the MDT therapy (21). However, in Hyderabad (India), only $50 \%$ of patients with leprosy reactions ex perienced an improvement in nerve function after treatment with steroids (6).

Pulse therapy using endovenous methylprednisolone is applied as an alternative to the oral corticosteroids to control reactional states. This method is used to reduce the side effects and period of morbidity. Indications for pulsotherapy are serious reversal reactions or reactions that are difficult to control using normal regimens, erythema nodosum, widespread and difficult to control erythema multiforme, and acute or chronic cases of neuritis where the patient has already undergone prolonged oral therapy with corticosteroids $(3,9)$. The dosage of this pulsotherapy 
is $1 \mathrm{gram}$ endovenous methylprednisiolone as a single daily dose during three days in the first week, followed by a 1 gram single weekly dose for four consecutive weeks, and followed again with 1 gram single monthly dose for four consecutive months. Between the pulse therapy dose, the patients are given 0.5 $\mathrm{mg} / \mathrm{kgBW} /$ day prednisone (9).

The steroid may also have physicochemical and genomic effects. The physicochemical effects are mediated by receptors or might work through other non-specific physicochemical activities. This effect might cause symptom improvement in a brief period of time, such as in terms of edema reduction. The genomic effects of steroids begin with the penetration of cell membranes by glucocorticoids, attachment of glucocorticoids to receptors, and steroid binding to DNA which influences the process of transcription, translation, the stability of mRNA and protein products. Glucocorticoids are known to inhibit $\mathrm{NF}_{-k} \mathrm{~B}$ activity, which is a transcription factor that regulates TNF- $a$, IL-1 $\beta$, IL-2 and inducible nitric oxide synthase (iNOS) $(15,21)$.

Another research done by Lockwood et al showed a significant decrease in interferon gamma (IFN- $y$ ), interleukin-2 (IL-2), and mainly TNF-a after 28 days of treatment with steroids (11). Similar results were also found in the study of Raju, et al. who studied 7 serological markers related to the pathogenesis of reversal reactions, namely TNF-a, antibodies to phenolic glycolipid-1 (PGL-1 IgM and IgG), lipoarabinomannan (IgG1 dan IgG3 LAM), C2-ceramide, and S100B. They found a decrease in the levels of TNF-a, C2-ceramide, S100B, PGL-1, dan LAM after onemonth prednisolone therapy (22). On the other hand, Anderrson et al. found that prednisolone was thought to have no effect on cytokines in the blood, and the effect was only localized to skin lesions. Furthermore, the effects obtained from prednisolone therapy might be caused by inhibition of the formation of prostaglandins and leukotrienes produced by mast cells and macrophages by the glucocorticoids, which ultimately functions as vasodilators and bronchoconstrictors. In addition, the effect of glucocorticoids can also be caused by non-specific nongenomic processes that result in changes in intracellular activity such as calcium and so- dium transport. This activity is known to be important for immune cell activation (15).

Lately, the concern has been put on the antioxidant profile in leprosy patients and leprosy patients that experienced an immunological reaction. A prospective study found a decrease in oxidative stress during clinical remission after reversal reaction treatment with prednisolone. However, residual oxidative stress still existed, rendering the increase of oxidative stress afterward. This study shows the importance of evaluating the addition of antioxidants as an adjuvant therapy for leprosy reversal reaction (23). Another study showed a decrease in uric acid levels after reversal reaction maximum dose $(40-80 \mathrm{mg} /$ day) prednisone therapy. This can be caused by increased uric acid excretion from the kidneys due to the effects elicited by the glucocorticoid. Uric acid is one of the antioxidant agents found in the body. Uric acid levels that are too high or too low are associated with mortality from cardiovascular disease and decreased kidney function (24).

There might be several side effects related to the prednisolone therapy, depending on the therapeutic dose and duration of treatment. Major side effects that possibly happen are peptic ulcer, diabetes, tuberculosis, hypertension, psychosis, glaucoma, cataracts, corneal ulcers, and parasitic infections. The minor side effects that possibly happen are heartburn, moon face, acne, local fungus infection, and weight gain, as found in the study of Wagenaar et al. (25).

A variety of alternative therapies are being developed as replacement therapy as well as adjuvant therapy. A study conducted by Lambert et al in patients who did not respond to prednisolone or in patients with severe side effects has shown cyclosporine to be an effective replacement therapy (26). Other studies have found that fusidic acid, which acts by affecting proinflammatory cytokines, is an effective and safe adjuvant therapy for leprosy reactions (27). Immunosuppressants, such as azathioprine and cyclosporine A can be used alone for reversal reactions, or can be used in association with corticosteroids as a corticosteroid sparing agent (28). Cyclosporin A inhibits the transcription of IL-12 mRNA, therefore the proliferation of $T$ cells will be blocked. Azatiophrine inhibits synthe- 
sis of nucleic acids and works in a much slower manner. With the invention of these adjuvant therapies, prednisolone dose can be reduced, therefore the adverse effect that occurred because of prednisone supplementation can be subsequently reduced.

Various studies have been developed to prevent nerve damage in leprosy. Nerve damage can occur without an immunological reaction. A study by Sahay, et al. recommends 8 months of prednisolone therapy for all multibacillary cases as a prophylaxis to prevent nerve damage, after comparing the control group that only underwent MDT therapy with the treatment group that received MDT plus prednisone $20 \mathrm{mg} /$ day, followed by tapering off at a $5 \mathrm{mg} / 2$ weeks dose in the seventh and eighth week. This was done to prevent deformities that would possibly happen in patients with leprosy (29). One study has found that the prophylaxis effect of prednisolone will continue to exist whilst patients are still taking the medicine, but the effect was found to be lost in the 12 months follow up (30). On the other hand, Wagenaar, et al do not recommend prednisolone to be given as prophylaxis medication after reviewing the effectivity of prednisolone use after 20 weeks and effectivity of prednisolone to treat neuropathies in cases with subclinical neuropathy (23).

\section{Conclusion}

Reversal reactions are immunological reactions that occur in leprosy patients and they are the biggest cause of disability in these patients. Glucocorticoids, especially prednisolone, have been established as standard therapy for reversal reactions. Many studies have shown that glucocorticoids, especially prednisolone, have genomic effects that affect cytokine regulation, but other studies have also shown the possibility that glucocorticoids actually work through non-specific non-genomic processes. However, there are a variety of side effects in prednisolone that may manifest clinically, as well as side effects on the antioxidant profile. Therefore, several studies have developed replacement therapy and adjuvant therapy for reversal reactions.

\section{References}

1. World Health Organization. Guidelines for the diagnosis, treatment, and prevention of leprosy. New Delhi: World Health Organization; 2018.

2. Pandhi D, Chhabra N. New insights in the pathogenesis of type 1 and type 2 lepra reaction. Indian J Dermatol Venereol Leprol. 2013;79(6):739-49.

3. Nery JA da C, Bernardes Filho F, Quintanilha J, Machado AM, Oliveira S de S, Sales AM. Understanding the type 1 reactional state for early diagnosis and treatment: a way to avoid disability in leprosy. An Bras Dermatol. 2013;88(5):787-92.

4. Scollard DM, Smith T, Bhoopat L, Theetranont C, Rangdaeng S, Morens DM. Epidemiologic characteristics of leprosy reactions [Internet]. Int J Lepr Other Mycobact Dis. 1994 [cited 2018 Dec 11];62(4):559-67. Available from: http://ila.ilsl.br/pdfs/v62n4a09.pdf

5. Kumar B, Dogra S, Kaur I. Epidemiological characteristics of leprosy reactions: 15 years experience from north India. Int J Lepr Other Mycobact Dis. 2004;72 (2):125-33.

6. Lockwood DN, Vinayakumar S, Stanley JN, Mcadam $\mathrm{KP}$, Colston MJ. Clinical features and outcome of reversal (type 1) reactions in Hyderabad, India. Int J Lepr Other Mycobact Dis. 1993;61(1):8-15.

7. Roche PW, Le Master J, Butlin CR. Risk factors for type 1 reactions in leprosy [Internet]. Int $\mathrm{J}$ Lepr Other Mycobact Dis. 1997 [cited 2018 Dec 12];65(4):450-5. Available from: http://ila.ilsl.br/pdfs/v65n4a02.pdf.

8. Motta AC, Pereira KJ, Tarquínio DC, Vieira MB, Miyake K, Foss NT. Leprosy reactions: coinfections as a possible risk factor. Clinics (Sao Paulo). 2012;67(10):1145-8.

9. Nery JA da C, Duppre NC, Sales AM, Machado AM, Jardim RM, Illarramendi X. Contribution to diagnosis and management of reactional states: a practical approach. An Bras Dermatol. 2006;81(4):367-75.

10. Kamath S, Vaccaro SA, Rea TH, Ochoa MT. Recognizing and managing the immunologic reactions in leprosy. J Am Acad Dermatol. 2014;71(4):795-803.

11. White C, Franco-Paredes C. Leprosy in the 21st century. Clin Microbiol Rev. 2015;28(1):80-94.

12. Naafs B. Clinical aspects of the reversal reaction. Hansenol Int. 1998;(Special):72-8.

13. Khadge S, Banu S, Bobosha K, van der Ploeg-van Schip JJ, Goulart IM, Thapa P, et al. Longitudinal immune profiles in type 1 leprosy reactions in Bangladesh, Brazil, Ethiopia and Nepal. BMC Infect Dis. 2015;15:477.

14. Geluk A, van Meijgaarden KE, Wilson L, Bobosha K, van der Ploeg-van Schip JJ, van den Eeden SJ, et al. Longitudinal immune responses and gene expression profiles in type 1 leprosy reactions. J Clin Immunol. 2014;34(2):245-55.

15. Andersson AK, Chaduvula M, Atkinson SE, KhanolkarYoung S, Jain S, Suneetha L, et al. Effects of prednisolone treatment on cytokine expression in patients with leprosy type 1 reactions. Infect Immun. 2005; 73(6):3725-33. 
16. Naafs B. Bangkok Workshop on Leprosy Research. Treatment of reactions and nerve damage. Int $\mathrm{J}$ Lepr Other Mycobact Dis. 1996;64(4 Suppl):S21-8.

17. Wagenaar IM. Risk factors, early detection and treatment of neuropathy in leprosy. Rotterdam: Erasmus University Rotterdam; 2016.

18. Oliveira MB, Diniz LM. Leprosy among children under 15 years of age: literature review. An Bras Dermatol. 2016;91(2):196-203.

19. Rose P, Waters MF. Reversal reactions in leprosy and their management. Lepr Rev. 1991;62(2):113-21.

20. Selvasekar A, Geetha J, Nisha K, Manimozhi N, Jesudasan K, Rao PS. Childhood leprosy in an endemic area. Lepr Rev. 1999;70(1):21-7.

21. Walker SL, Lockwood DNJ. Leprosy type 1 (reversal) reactions and their management. Lepr Rev. 2008;79 (4):372-86.

22. Raju R, Suneetha S, Jadhav RS, Chaduvula M, Atkinson S, Jain S, et al. Serological responses to prednisolone treatment in leprosy reactions: study of TNF-a, antibodies to and S100-B. Lipids Health Dis. 2014;13:119.

23. Chhabra N, Bhattacharya SN, Singal A, Ahmed RS, Verma P. Profile of oxidative stress in response to treatment for type 1 leprosy reaction. Lepr Rev. 2015;86(1):80-8.

24. Morato-Conceicao YT, Alves-Junior ER, Arruda TA, Lopes JC, Fontes CJ. Serum uric acid levels during leprosy reaction episodes. PeerJ. 2016;4:e1799.
25. Wagenaar I, Post E, Brandsma W, Bowers B, Alam K, Shetty $\mathrm{V}$, et al. Effectiveness of 32 versus 20 weeks of prednisolone in leprosy patients with recent nerve function impairment: a randomized controlled trial. PLoS Negl Trop Dis. 2017;11(10):e0005952.

26. Lambert SM, Alembo DT, Nigusse SD, Yamuah LK, Walker SL, Lockwood DN. A randomized controlled double blind trial of ciclosporin versus prednisolone in the management of leprosy patients with new type 1 reaction, in Ethiopia. PLoS Negl Trop Dis. 2016;10 (4):e0004502.

27. Gabriel MTG, Hipolito RH, Chan GP, Senador LR, Lagda D, Gajete FC. Safety and efficacy of oral fusidic acid as a steroid-sparing agent in the treatment of lepra reactions : a randomized controlled assessorblinded clinical trial. Journal of the Philippine Dermatological Society. 2015;24(2):20-9.

28. Durães SM, Salles Sde A, Leite VR, Gazzeta MO. Azathioprine as a steroid sparing agent in leprosy type 2 reactions: report of nine cases. Lepr Rev. 2011;82(3):304-9.

29. Sahay G, Kar HK, Gupta R. Effect of steroid prophylaxis on nerve function impairment in multi-bacillary leprosy patients on MDT-MB. Indian J Lepr. 2015;87(3):133-43.

30. Smith WC, Anderson AM, Withington SG, van Brakel WH, Croft RP, Nicholls PG, et al. Steroid prophylaxis for prevention of nerve function impairment in leprosy: randomised placebo controlled trial (TRIPOD 1). BMJ. 2004;328(7454):1459.

\section{Glukokortikoidi u reverziblinim reakcijama kod lepre}

\section{Sažetak}

Lepra je oboljenje izazvano Mycobacterium leprae i ona dovodi do deformacija i unakaženja bolesnika. Za lečenje lepre primenjuje se nekoliko lekova, međutim, ta terapija može izazvati leprozne reakcije kod pacijenta. Ima nekoliko tipova leprozne reakcije: reakcija tipa 1, reakcija tipe 2 i neuritis. Reakcija tipa 1 se uglavnom pojavljuje u BB, BI i BT oblicima lepre $\mathrm{i}$ ispoljava se pogoršanjem postojećih lezija. Terapija za ovu reakciju prema smernicama SZO je kortikosteroidna terapija. U ovom radu ćemo objasniti nekoliko ključnih momenata u vezi sa kortikosteroidnom terapijom kod reverzibilnih reakcija lepre, uključujući i neželjene efekte i raspoložive alternativne terapije.

Ključne reči: Lepra; Profil ekspresije gena; Glukokortikoidi; Komorbiditet; Dijagnoza; Prednizolon; Indonezija

Received 26.02.2019.

Accepted 10.03.2019. 